\section{Høyresidig aortabue}

Tidlig i fosterlivet finnes det to aortabuer, men vanligvis tilbakedannes den høyre. Noen ganger persisterer begge aortabuene (vaskulær ring) eller det er den venstre som tilbakedannes. Trachea og oesophagus blir i disse tilfellene liggende mellom aorta og lungearterien. Figur 1 og 2 og tilhørende videoer, som finnes til denne artikkelen på www.tidsskriftet.no, viser et eksempel på persisterende høyre aortabue. Studier i den voksne befolkningen har vist en prevalens på $1 \%$, men persisterende høyre aortabue påvises bare hos ca. $0,1-0,2 \%$ ved ultralydundersøkelse av foster. Tilstanden kan være forbundet med kompliserte hjertefeil. Prognosen er vanligvis god ved isolert persisterende høyre aortabue, og man forventer ikke problemer i svangerskapet. Kompresjon av oesophagus og trachea kan gi problemer etter fødselen, og barnelege bør derfor være til stede ved fødselen. Hvis tilstanden forekommer i kombinasjon med andre fosteravvik, er det økt sannsynlighet for kromosomavvik som trisomi 21 eller DiGeorges syndrom.

Persisterende høyre aortabue kan diagnostiseres ved den rutinemessige ultralyd- undersøkelsen i andre trimester. I tverrsnitt gjennom brystet kan man se forløpet til avgangskarene fra fosterhjertet. Vanligvis går både lungearterien og aorta til venstre for trachea. Bruk av fargedoppler gjør det lettere å oppdage tilstanden.

\section{Torbjørn Moe Eggebø}

tme@lyse.net

Claudia Heien

Ultralydlaboratoriet, fødeavdelingen

Stavanger universitetssjukehus

Armauer Hansensvei 20

4068 Stavanger

Pasientens foresatte har gitt samtykke til at artikkelen blir publisert.

Oppgitte interessekonflikter: Torbjørn Eggebø har fått dekket reiseutgifter og kursavgift til et opplæringskurs i 3D-ultralyd i Berlin av firmaet som har levert ultralydapparatet som er brukt $i$ denne artikkelen. Claudia Heien arbeider to dager i måneden for dette firmaet.

Manuskriptet ble mottatt 9.5. 2010 og godkjent 8.7. 2010. Medisinsk redaktør Michael Bretthauer.
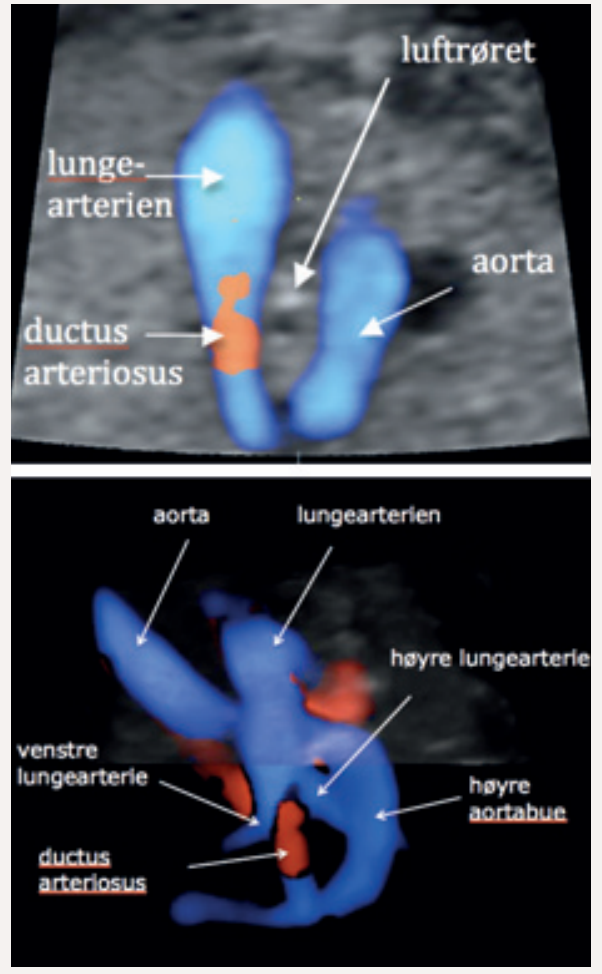